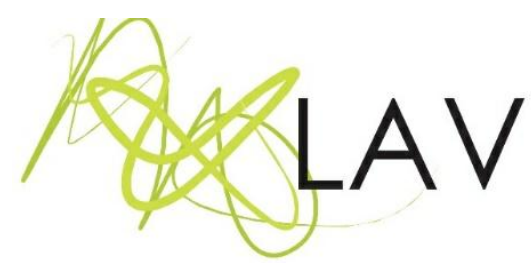

\title{
Análise da animação o menino e o mundo (2013): significados visuais acerca do desenho infantil e das infâncias
}

\author{
Analysis on the animation o menino e o mundo [boy and the world] (2013): visual \\ meanings about childhood and childhood drawing
}

\author{
João Paulo Baliscei \\ Universidade Estadual de Maringá \\ Emilly Anselmo Pereiraii \\ Universidade Estadual de Maringá
}

\begin{abstract}
Resumo
O presente artigo atribui ênfase para O Menino e o Mundo (2013) - uma animação dirigida por Alê Abreu, e que desempenha tratamentos inusitados para o verbal e o visual. A animação trata sobre a infância e, por isso, a linguagem verbal (falada e escrita) é apresentada de modo distorcido. Quais significados acerca da infância podem ser produzidos a partir das visualidades fílmicas de O Menino e o Mundo (2013)? Propõese investigar as características estéticas da animação em questão, relacionando-as com o desenho infantil e com significações sobre as infâncias. Para isso, analisou-se O Menino e o Mundo (2013), tendo os Estudos da Cultura Visual como referencial teórico (CUNHA, 1999; 2017; SARDELICH, 2006; HERNÁNDEZ, 2007; BALISCEI, 2020). As cenas foram aproximadas de pesquisas que conferem significados ao desenho infantil, sublinhando o protagonismo dado à ótica da criança.
\end{abstract}

Palavras-chave: Cultura Visual, arte, imagem, cinema, criança.

Abstract

This article emphasizes O Menino e o Mundo [Boy and the World] (2013) - an animated movie directed by Alê Abreu, and which performs unusual treatments for the verbal and the visual: the animated movie deals with childhood and, therefore, the verbal language (spoken and written) is presented in a distorted way. What meanings about childhood can be produced from the filmic visualities of O Menino e o Mundo [Boy and the World] (2013)? Therefore, it proposes, as an objective, to investigate as aesthetic characteristics of the animated movie in question, to relate to the children's drawing and meanings about childhood. For that, $O$ Menino e o Mundo [Boy and the World] (2013) was analyzed, having the Studies of Visual Culture as a theoretical reference (CUNHA, 1999; 2017; SARDELICH，2006; HERNÁNDEZ, 2007; BALISCEI, 2020). The scenes were approached by researches that give meaning to children's drawing, underlining the protagonism given to the child's perspective.

Keywords: Visual Culture, art, image, cinema, child. 


\section{Entre o visual e o verbal: espaços e sobreposições}

Vivemos em um mundo visual. Tomando a visão como algo 'natural - como um conjunto de mecanismos fisiológicos do cérebro - algumas das pessoas acabam não extraindo grande parte da potencialidade de informações que podem estar contidas dentro de uma única imagem. Para além do funcionamento do aparelho visual, composto pelo globo ocular, pelo cristalino, pela retina e suas células fotossensíveis, as córneas e também pelo nervo ótico, que capta os estímulos visuais que nos rodeiam, há a assimilação feita pelo nosso cérebro, a qual pode ser orientada. Em outras palavras, na introdução deste artigo, chamamos a atenção para o fato de que somos ensinados/as a ler/compreender as imagens com as quais interagimos, semelhantemente ao modo como somos ensinados/as a ler/compreender textos verbais - porém, a partir de investimentos diferentes.

Desde pequenas, as crianças são incentivadas por seus e suas familiares e por instituições escolares a aprender a linguagem verbal e a se familiarizar com a fala, com a escrita e com seus significados - o que é importante para o seu desenvolvimento social e cognitivo. Contudo, as imagens com as quais as crianças estão em contato diariamente (sobretudo aquelas que vivem em sociedades ocidentais, com acesso e apelo ao consumo e às mídias virtuais) também são constituídas de significados. Por isso, parece-nos apropriado que os sujeitos contemporâneos possam estar aptos também a perceber e analisar a complexidade das informações intrínsecas às imagens, e sublinhamos, pois, a necessidade e a urgência de pensar em uma educação preocupada com a análise da cultura visual.

Lúcia Santaella (2012, p. 13) contribui para essa discussão quando reclama por uma alfabetização visual, prática que, segundo a autora, implica "[...] aprender a ler imagens, desenvolver a observação de seus aspectos e traços construtivos, detectar o que se produz no interior da própria imagem". Para tanto, sugere que, na Educação Básica, as e os professores podem orientar exercícios de leitura e análise de imagens, visando compartilhar com seus alunos e alunas os significados extraídos de uma produção artística, por exemplo. No entanto, a realidade das escolas brasileiras não parece ser essa, já que a ênfase da ação pedagógica, da formação docente e dos próprios currículos tem sido o desenvolvimento da linguagem verbal. Assim, nas palavras da autora, as instituições escolares acabam por "[...] negligenciar a alfabetização visual de seus educandos" (SANTAELLA, 2012, p. 14). Em concordância com a autora, buscamos a valorização das Artes Visuais como área do conhecimento indispensável 
também no cotidiano e que pode contribuir para aquilo que ela chama de alfabetização visual.

Mas por que a linguagem verbal é mais valorizada e ensinada em relação à linguagem visual? Segundo Ana Angélica Albano Moreira (2008), na contemporaneidade, as crianças vivem em uma sociedade que foi se transformando, ao longo do tempo; onde, com o crescimento urbano e o desenvolvimento tecnológico, a escola passou a desempenhar um papel de 'quintal' para as crianças. Isso porque, segundo a autora, as crianças já não podem brincar livremente pela rua. Além disso, as famílias têm tido cada vez menos filhos/as e, com isso, as crianças acabaram perdendo o contato com outras crianças da família, da rua ou do bairro.

Diante desse contexto, paulatinamente, à escola foi destinado esse papel de promover o espaço de ampliação de experiências afetivas para as crianças pequenas. Contudo, para satisfazer os desejos dos e das familiares e as necessidades imediatas de uma sociedade capitalista, a escola tem antecipado cada vez mais a alfabetização das crianças, deixando de lado aquelas consideradas como suas primeiras expressões, como o brincar e o desenhar, para aprender uma linguagem ensinada. Sobre isso, concordamos com Moreira (2008, p. 68) quando destaca:

Não me coloco absolutamente contra o aprendizado do código verbal. O que pretendo é chamar a atenção para um fato, que a alfabetização precoce apenas antecipa, mas que se prolonga durante todo o processo de escolarização: é a supervalorização de um ensino verbal, calcado em atividades intelectuais e abstratas, em detrimento da descoberta, do jogo, da criação e da pesquisa.

Na Base Nacional Comum Curricular (BNCC), documento recentemente formulado com objetivo de oferecer diretrizes aos diferentes níveis da Educação Básica brasileira, sugerem-se fundamentos para a Educação Infantil, destinada às crianças de até cinco anos, assegurando o direito do sujeito infantil de "conviver, brincar, participar, explorar, expressar-se e conhecer-se" (BRASIL, 2018, p. 40). Nesse sentido, aproximamos a concepção de escola e de infância aferida por tal documento com a metáfora estabelecida por Moreira (2008) entre 'quintal' e escola. Outra questão que corrobora as análises de Moreira (2008) é que, na BNCC, já nos primeiros anos do Ensino Fundamental, destinado às crianças a partir de seis anos de idade, a alfabetização e a linguagem verbal tomam o protagonismo das práticas de ensino - o que fica evidente, por exemplo, nos grifos que enfatizamos do excerto extraído abaixo:

No Ensino Fundamental - Anos Iniciais, os componentes curriculares tematizam diversas práticas, considerando especialmente aquelas relativas às culturas infantis tradicionais e 
contemporâneas. Nesse conjunto de práticas, nos dois primeiros anos desse segmento, o processo de alfabetização deve ser o foco da ação pedagógica. Afinal, aprender a ler e escrever oferece aos estudantes algo novo e surpreendente (BRASIL, 2018, p. 63, grifos nossos).

Nessa fase de alfabetização das crianças, a expressão visual e o brincar são, de maneiras ora mais ora menos sutis, substituídos pelo verbal. A criança 'rompe' com o desenho, que até então era uma de suas formas de expressão de pensamento, e é incentivada a desenvolver uma forma de pensamento mais lógica e adulta. Ocorre que os signos visuais são importantes na infância justamente pelo fato de que os pensamentos das crianças são compostos também por imagens, expressos nos desenhos que elas produzem. Com a ênfase dada à linguagem verbal, o desenvolvimento artísticoexpressivo que a criança teve até esse momento da alfabetização acaba sendo 'interrompido', e a consequência disso está implícita, por exemplo, em uma frase 'ilusória', comumente dita por adultos/as e crianças: 'eu não sei desenhar' - sobre a qual debatemos em um outro estudo (BALISCEI; LACERDA; TERUYA, 2018). Em uma terceira pesquisa nossa (LACERDA; BALISCEI; TERUYA, 2017), investigamos desenhos de crianças e de idosas e corroboramos o pensamento de Moreira (2008) que supõe que, se analisarmos os desenhos de adultos/as que alegam 'não saber desenhar', provavelmente, constataremos que esse desenho é semelhante aos estereótipos feitos por crianças. As observações realizadas por Susana Rangel Vieira da Cunha (1999) guardam relação com essa análise e contribuem para a consolidação da hipótese de que o adulto ou a adulta que afirma não saber desenhar, provavelmente, foi uma criança cujo desenvolvimento artístico-expressivo foi interrompido. Nas palavras de Cunha (1999, p. 9, grifos da autora):

[...] a maioria dos adultos (nós, professores) se esqueceu desta linguagem tão rica e prazerosa que foi deixada para trás por volta dos 7 ou 8 anos, quando saiu da escola infantil e passou para a escola que valoriza mais a linguagem verbal (escrita e falada). Ao interromper, na sua infância, o desenvolvimento da linguagem gráfico-plástica, foram fixadas formas padronizadas como a casinha, a árvore com maçãs, as nuvens azuis, o sol, as flores, a figura humana de palito, organizando-se um repertório reduzido de formas que chamamos de estereótipos.

Quando nos deparamos com uma imagem desacompanhada de legendas, textos e outros recursos escritos - onde a linguagem verbal é deixada de lado e linguagem visual toma o foco -, somos levados a examinar a visualidade sozinha e a atribuir significados aos seus signos de outras maneiras para além daquelas convencionais, nas quais o verbal se sobressai ao artístico-expressivo. Ocorre que, em museus, galerias e exposições, as obras visuais costumam estar acompanhadas de legendas com 
informações como o título da obra, o ano em que foi produzida, o nome do ou da artista e orientações que balizam o nosso olhar. Poderíamos, sim, realizar leituras ou análises visuais sem a presença de uma legenda, recorrendo, por exemplo, aos elementos formais da produção, aos afetos que nos causa a cena em questão ou até mesmo à significação a partir de nossas próprias vivências. Entretanto, consideramos que essas relações entre palavra e imagem, apesar de culturalmente hierárquicas, auxiliam-nos para determinados direcionamentos. Ter o conhecimento do ano e local da obra, por exemplo, pode nos dizer muito do contexto histórico que a envolve, conduzindo-nos à formulação de pensamentos que poderiam não ser considerados sem o acesso a tais informações assim como um título, pode também provocar e disparar a respeito de certo tema, pessoa, lugar, contexto.

Em um mural produzido por Banksy - artista urbano anônimo - por exemplo, ele representou Steve Jobs segurando, com uma mão, um saco de lixo sobre o ombro, e com a outra, um computador antigo. Essa imagem, sem a presença de uma legenda com informações sobre o ano, local e título, pode nos levar à leitura de uma crítica à pessoa representada, ou até mesmo nos remeter ao sucesso que ele obteve na construção da sua marca, a Apple. Contudo, com a apresentação do título O Filho de um Imigrante da Síria (2015) e também com o conhecimento do local onde a obra fora realizada, é possível criar outros significados ${ }^{1}$.

Por outro lado, outra obra cujo título não é necessariamente descritivo do local, período, ou contexto histórico de sua produção, pode sugerir significados mais abrangentes do que aqueles identificados de imediato. Em uma das obras do artista cubano Félix González-Torres (1957-1996), por exemplo, ele apresenta dois relógios idênticos: brancos, comuns, de ponteiros, que marcam o mesmo horário. Inicialmente, os relógios que operam por bateria estavam sincronizados, porém, aos poucos, perdem sua simultaneidade, até que um deles para - o que nos permite aferir diversas significações a respeito do tempo, ou também como uma metáfora para o amor. O título inusitado da obra, Perfect Lovers (1991), impulsiona-nos a procurar novos significados (também menos óbvios), relacionados ao amor, à morte e à perda².

\footnotetext{
${ }^{1}$ Trata-se de uma pintura numa parede do campo de refugiados de Calais, onde vivem mais de 6.000 pessoas, muitas vindas da Síria. A partir disso, é possível elaborar pensamentos referentes à crise dos refugiados vindos da Síria e de tantos outros lugares em direção da França e de toda a Europa. Essas pessoas, na maioria das vezes, não são bem-vindas nesses países.

$2 \mathrm{O}$ artista sincronizou os relógios no mesmo horário, fazendo referência ao início de um romance, por exemplo. A obra tem ainda mais significações ao saber que o artista a criou enquanto seu parceiro, Ross Laycock, estava morrendo de AIDS. Pouco a pouco, os relógios acabavam se dessincronizando, e o tempo entre eles ficava cada vez mais distante, até finalmente um deles parar.
} 
Com esses exemplos, queremos evidenciar que a linguagem verbal que acompanha/compõe a produção artística, paradoxalmente, restringe e amplia a significação visual. Assim, a linguagem visual e a linguagem verbal não devem ser tratadas como linguagens 'rivais', mas apenas linguagens distintas, com modos de representação de significados próprios em cada universo, que podem inclusive, como exemplificamos, cooperar para a significação artística. Segundo Santaella (2012), as duas linguagens se complementam, de maneira que uma não pode substituir inteiramente o outra.

Além disso, até mesmo a própria linguagem verbal é composta por uma visualidade. Nela podemos observar a escolha da fonte, do formato e das cores. As artistas estadunidenses Barbara Krueger (1945--) e Jenny Holzer (1950--), por exemplo, utilizam da estética tipográfica para a produção de seus trabalhos artísticos. Em Untitled (Your Body Is a Battleground, 1989), Barbara Krueger recorre à fotografia em preto e branco e às letras com grifos em vermelho que já Ihes são características, e, em Blue Purple Tilt (2007), Jenny Holzer parodia a tecnologia digital, servindo-se de luzes de LED para constituir frases que se movem rapidamente. As quatro obras mencionadas até então podem ser observadas na Figura 1.

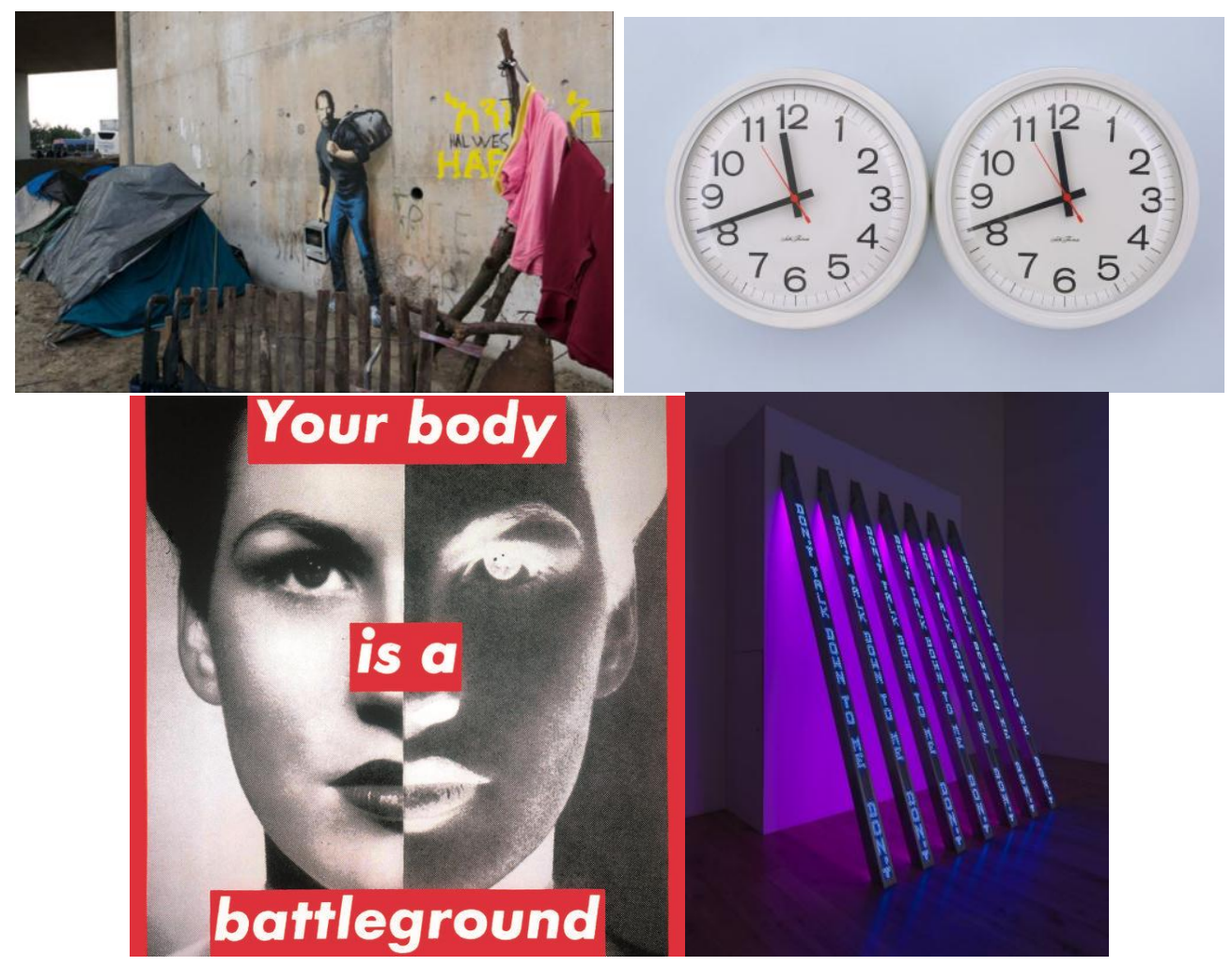

Figura 1: Relações entre visual e verbal

Fonte: O Filho de um imigrante da Síria (2015); Perfect Lovers (1991); Untitled (Your Body Is a Battleground) (1989); e Blue Purple Tilt (2007) 
Para além dessas expressões da Arte Contemporânea, uma produção mais recente, o filme de animação O Menino e o Mundo (2013), propõe relações inusitadas e pouco convencionais entre a linguagem visual e a verbal, por isso a tomamos como objeto de análise neste artigo. O Menino e o Mundo (2013) é uma animação nacional dirigida pelo paulista Alê Abreu (1971--), lançada no Brasil em janeiro de 2014 e que concorreu ao Óscar em 2016 como melhor animação ${ }^{3}$. O filme conta a história de uma criança que mora no interior e vê seu pai indo embora em direção à cidade em busca de trabalho. O filme retrata fundamentalmente o ponto de vista da criança e sua forma de enfrentar o mundo e os desafios que a mudança para a cidade Ihe acarreta.

Graficamente, os elementos visuais do filme reforçam a visão da criança, podendo ser identificados no uso das cores, das texturas, dos materiais e das distorções que atuam como metáfora da visão poética característica da infância que, diante de grandes máquinas, por exemplo, enxerga 'monstros'. Os diálogos verbais apresentados no filme também são incompreensíveis, semelhantemente aos assuntos 'do mundo adulto' que as crianças, por vezes, ainda não conseguem entender. Quando o pai, a mãe ou outro/a adulto/a conversam, os sons que emitem são distorcidos - uma 'língua inventada' cujos significados não nos são acessíveis. Descobrimos, por fim, que os diálogos foram gravados em uma espécie de português 'invertido', no qual a sonoridade de cada palavra fora experimentada 'de trás para frente'.

Quais significados acerca da infância podem ser produzidos a partir das visualidades fílmicas de O Menino e o Mundo (2013)? Para responder essa pergunta, temos como objetivo investigar as características estéticas da animação em questão, relacionando-as com o desenho infantil e com significações sobre a infância. Para isso, damos ênfase na percepção de mundo representada pela e na ótica do personagemcriança e aproximamos as cenas extraídas da animação de pressupostos dos Estudos da Cultura Visual (SARDELICH, 2006; HERNÁNDEZ, 2007; BALISCEI, 2020) e de pesquisas acerca do desenho infantil (CUNHA, 1999; 2017; RICHTER, 1999; EDWARDS, 2000; VIANNA, 2010; MOREIRA, 2008; IAVELBERG, 2013). Além disso, detalhamos o processo de criação e produção de O Menino e o Mundo (2013), recorrendo a documentários de making of e entrevista com o diretor Alê de Abreu, e debatemos sobre as técnicas e elementos que compõem a singularidade do filme.

${ }^{3}$ No ano de 2016, o vencedor do Óscar na categoria Melhor Animação foi Divertida Mente (2015). 


\section{Abordagem Formalista e Estudos da Cultura Visual: possibilidades analíticas}

A apresentação que fizemos a respeito de O Menino e o Mundo (2013) na introdução deste artigo, ainda que sucinta, possibilita-nos sublinhar, de antemão, que no filme há destaque para a significação visual, sendo os elementos formais das Artes Visuais representações dos pensamentos, gostos, desejos, sentimentos e medos de Cuca - o garoto protagonista. Isso nos remete aos estudos de Donis A. Dondis (2014), que apresenta os elementos formais das Artes Visuais como uma espécie de caixa de ferramentas úteis para a comunicação visual. Ponto, Forma, Direção, Tom, Cor, Textura, Escala, Dimensão e Movimento são, segundo a autora, os elementos formais a partir dos quais se delineiam as diversas produções visuais. Nas palavras de Dondis (2014, p. 18):

A sintaxe visual existe. Há linhas gerais para a criação de composições. Há elementos básicos que podem ser aprendidos e compreendidos por todos os estudiosos dos meios de comunicação visual, sejam eles artistas ou não, e que podem ser usados, em conjunto com técnicas manipulativas, para a criação de mensagens visuais claras. O conhecimento de todos esses fatores pode levar a uma melhor compreensão das mensagens visuais.

Dessa maneira, Dondis (2014) evidencia uma forma de visualizar as imagens constituídas por elementos formais básicos, que estruturam e significam o que vemos, a qual ela se refere como Sintaxe da Linguagem Visual. Portanto, considera que a criação de uma imagem pode ser alicerçada ao uso de técnicas e combinações específicas, por meio de contrastes e harmonizações cromáticas, por exemplo, para que determinados efeitos sejam alcançados.

Semelhantemente, Lucia Santaella (2012) toma esses mesmos elementos como ponto de partida para discutir sobre a leitura de imagem e a alfabetização visual. Para ela, não somos leitores/as apenas ao aprender a ler as palavras de uma língua, mas também o somos quando decodificamos os signos presentes nas imagens. Contudo, para ela, o visual e o verbal se constituem como linguagens distintas e, neste ponto, concorda com Cunha (1999) e Moreira (2008) ao denunciar a demasiada valorização que as escolas conferem ao verbal em detrimento ao desenvolvimento artístico-visual.

Maria Emília Sardelich (2006) também defende a necessidade de alfabetização visual em contextos escolares, porém, sublinha as divergências epistemológicas e conceituais entre a Abordagem Formalista e os Estudos da Cultura Visual - referencial teórico esse, cujos pensamentos e concepções a autora compartilha. Segundo ela, a 
Abordagem Formalista ${ }^{4}$ teve destaque, sobretudo por volta de 1970, em meio à propagação dos sistemas audiovisuais e à prática de leitura de imagens fundamentadas na teoria da Gestalt e da Semiótica. Explica que a "[...] proposta da leitura de imagens de tendência formalista fundamenta-se em uma 'racionalidade' perceptiva e comunicativa que justifica o uso e desenvolvimento da linguagem visual para facilitar a comunicação" (SARDELICH, 2006, p. 454).

Sendo assim, Sardelich (2006) apresenta os Estudos da Cultura Visual como um contraponto à restrição configurada pelos elementos formais das Artes Visuais que fundamentam leituras e produções a partir da Abordagem Formalista. Segundo ela, os Estudos da Cultura Visual buscam uma visão mais ampla e complexa acerca dos significados produzidos a partir de uma imagem. A abordagem dos Estudos da Cultura Visual "[...] fundamenta-se em uma base socioantropológica, o que significa focalizar o conhecimento tanto nos produtores dessas experiências [visuais] quanto no contexto sociocultural em que são produzidas" (SARDELICH, 2006, p. 462). Assim, a autora apresenta não só uma vertente que dá ênfase para o visual, como também atribui protagonismo ao sujeito que interage com aquilo que é visualmente perceptível, o que nos remete aos estudos de Fernando Hernández (2007).

Hernández (2007) considera os sujeitos menos como leitores/as e decodificadores/as de imagens e mais como construtores/as ou intérpretes visuais. Por isso, em seus estudos, prefere se utilizar da expressão intérpretes visuais, a qual destaca que as aproximações estabelecidas entre sujeitos e imagens não são meramente passivas, mas sim interativas, transitórias, mútuas e dinâmicas. Nessa perspectiva, portanto, durante a produção e análise de imagens, os olhares construídos pelos/as intérpretes visuais carregam as experiências, valores e imaginários de uma determinada sociedade, cultura e tempo. Isso significa que a leitura de imagem nunca é apenas uma 'leitura' em si - no sentido de ser uma "extração" de códigos - e que não se pauta exclusivamente nos elementos formais das Artes Visuais. Para além dos aspectos plásticos e estéticos, outras camadas interpretativas podem ser completadas, tais como as subjetivas, sociais, antropológicas, políticas e identitárias.

Em outra pesquisa (BALISCEI, 2020), temos destacado o caráter problematizador e o interesse de analisar artefatos populares e acessíveis como uma das principais características dos Estudos da Cultura Visual. Nela, mais precisamente, desafiamo-nos a investigar a construção visual das masculinidades em 20 personagens (heróis, vilões e

\footnotetext{
${ }^{4}$ A autora, inclusive, destaca Dondis (2014) como uma das fundadoras da Abordagem Formalista, pois na concepção de Sintaxe Visual, há, segundo ela, formas de interpretar a informação visual a partir de um sistema básico de aprendizagem e compreensão das imagens.
} 
coadjuvantes) de animações da Disney. As análises e os resultados que apresentamos sublinham que os artefatos culturais do cotidiano, tais como os filmes de animação, atuam não apenas no âmbito do entretenimento e do prazer, mas também produzem significados identitários, políticos e culturais. Diante disso, neste artigo, consideramos ser possível e pertinente investigar as características estéticas de $O$ Menino e o Mundo (2013) para além do âmbito plástico e relacioná-las com outras questões, a exemplo do desenho infantil e das significações sobre infância.

\section{Significados visuais acerca da infância: o mundo a partir da ótica de Cuca}

A animação brasileira O Menino e o Mundo (2013), dirigida pelo animador e diretor de cinema brasileiro Alê Abreu, rodou o mundo em festivais, sendo exibida comercialmente em mais de 100 países. Segundo o diretor, o longa surgiu de outro documentário animado que, depois de produzido, chamar-se-ia Canto Latino e teria uma narrativa sobre a América Latina. Um dos personagens elaborados para Canto Latino - o garoto chamado pela produção de Cuca - acabou roubando a cena e levando o filme inicial para outro caminho. Assim, as partes da história atuaram como uma espécie de peças de quebra-cabeça a partir das quais a equipe foi constituindo a história de maneira fluída.

Para a elaboração da trilha sonora, O Menino e o Mundo (2013) contou com a participação do músico pernambucano Naná Vasconcelos (1944-2016), do grupo Barbatuques, do Grupo Experimental de Música (GEM) e do rapper paulistano Emicida (1985--). Para a composição da trilha sonora, Naná Vasconcelos utilizou-se da percussão com diversas materialidades inusitadas, como uma panela, além de outros instrumentos e da sua própria voz para compor a sonoplastia que caracteriza a natureza, os bichos e as plantas da animação. O grupo Barbatuques também participou da musicalização da animação de modo pouco convencional, utilizando-se das vozes e dos sons que os e as integrantes do grupo produziam com seus próprios corpos. O GEM, por sua vez, recorreu a instrumentos musicais produzidos a partir de objetos do cotidiano, como canos, sucatas e materiais recicláveis, combinados à percussão e a sintetizadores. Na Figura 2, reunimos registros de Naná Vasconcelos e de um integrante do GEM produzindo som a partir de uma panela e de materiais recicláveis, respectivamente. 

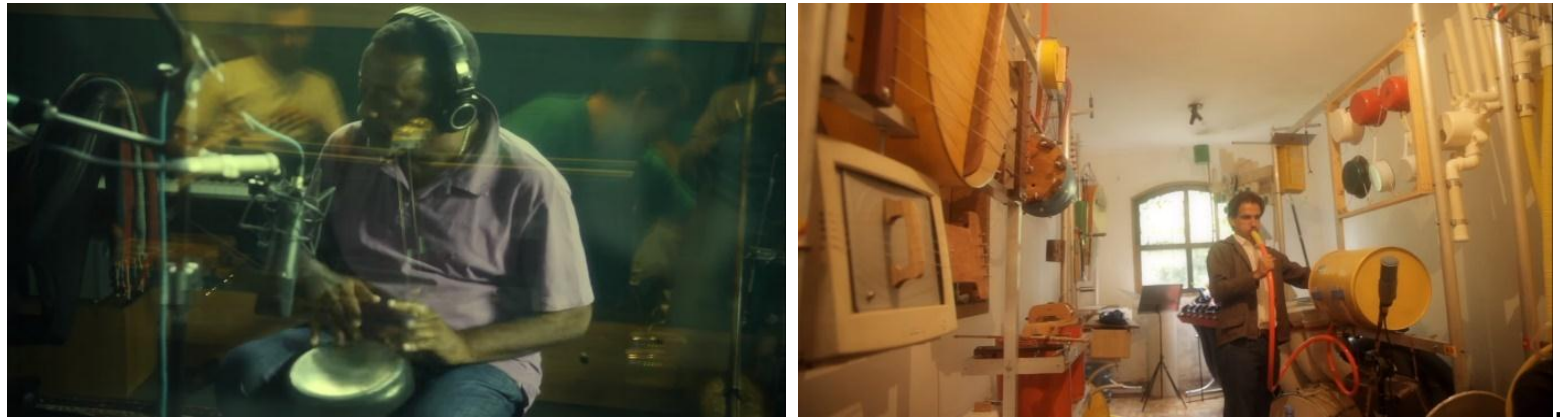

Figura 2: Naná Vasconcelos e Grupo Experimental de Música

Fonte: Prints Screen capturados em 10'56" e 0'32", respectivamente, do vídeo localizado no YouTube: <https://www.youtube.com/watch?v=dWL40XjLhv0>.

A participação do rapper Emicida na trilha sonora de O Menino e o Mundo (2013) ocorreu na composição da música que é tema principal do filme, intitulada Aos olhos de uma criança ${ }^{5}$, a qual aborda a premissa do filme: a busca do menino pelo pai.

Para além desses aspectos, consideramos que a trilha sonora de $O$ Menino e $o$ Mundo (2013) torna-se especial por um outro fator que guarda relação com os interesses e inquietações que manifestamos na introdução deste artigo: as assimetrias entre o verbal e visual. Semelhantemente aos diálogos que foram produzidos em um 'português invertido', de modo a tornar as conversas 'incompreensíveis', também as palavras e as frases que integram as músicas da trilha sonora de O Menino e o Mundo (2013) foram pronunciadas e gravadas 'de trás para frente'. Mesmo a música composta por Emicida foi regravada por ele durante a produção do filme, com as palavras também pronunciadas numa ordem contrária a habitual.

Assim, consideramos que a música fora inserida no filme de maneira coerente, isto é, mantendo a proposta de valorização da linguagem visual, como ocorre nas demais cenas de personagens falando ou cantando 'de trás pra frente'. Quando o pai e a mãe de Cuca conversam, por exemplo, ou quando um jornalista é mostrado na tela da televisão, as palavras que proferem são invertidas. Essa característica conceitual que atravessa as várias camadas de produção da animação faz com que os diálogos só possam ser compreendidos pela entonação das vozes, ou ainda, pelos aspectos visuais presentes nas expressões e movimentos dos/as personagens.

Interessante mencionar que, além das palavras pronunciadas e das palavras cantadas, na animação, também as palavras escritas são apresentadas numa ordem pouco convencional à linguagem verbal. Na figura 3, reunimos algumas cenas nas quais,

\footnotetext{
${ }^{5}$ O clipe e letra da música podem ser acessados a partir do link: <https://youtu.be/cpOb3db_Xuc>. Acesso em: 02 nov. 2019.
}

Revista Digital do LAV - Santa Maria - vol. 13, n. 3, p. 05 - 30 - set./dez. 2020 ISSN 1983 - 7348 http://dx.doi.org/10.5902/1983734841970 
ao invés de mostrar representações gráficas da escrita comumente, recorreram-se a símbolos cortados, distorcidos ou invertidos. Mesmo quando aparecem 'palavras', as letras são misturadas e alteradas de forma que não conseguimos decodificá-las a partir dos significados que já nos são conhecidos.
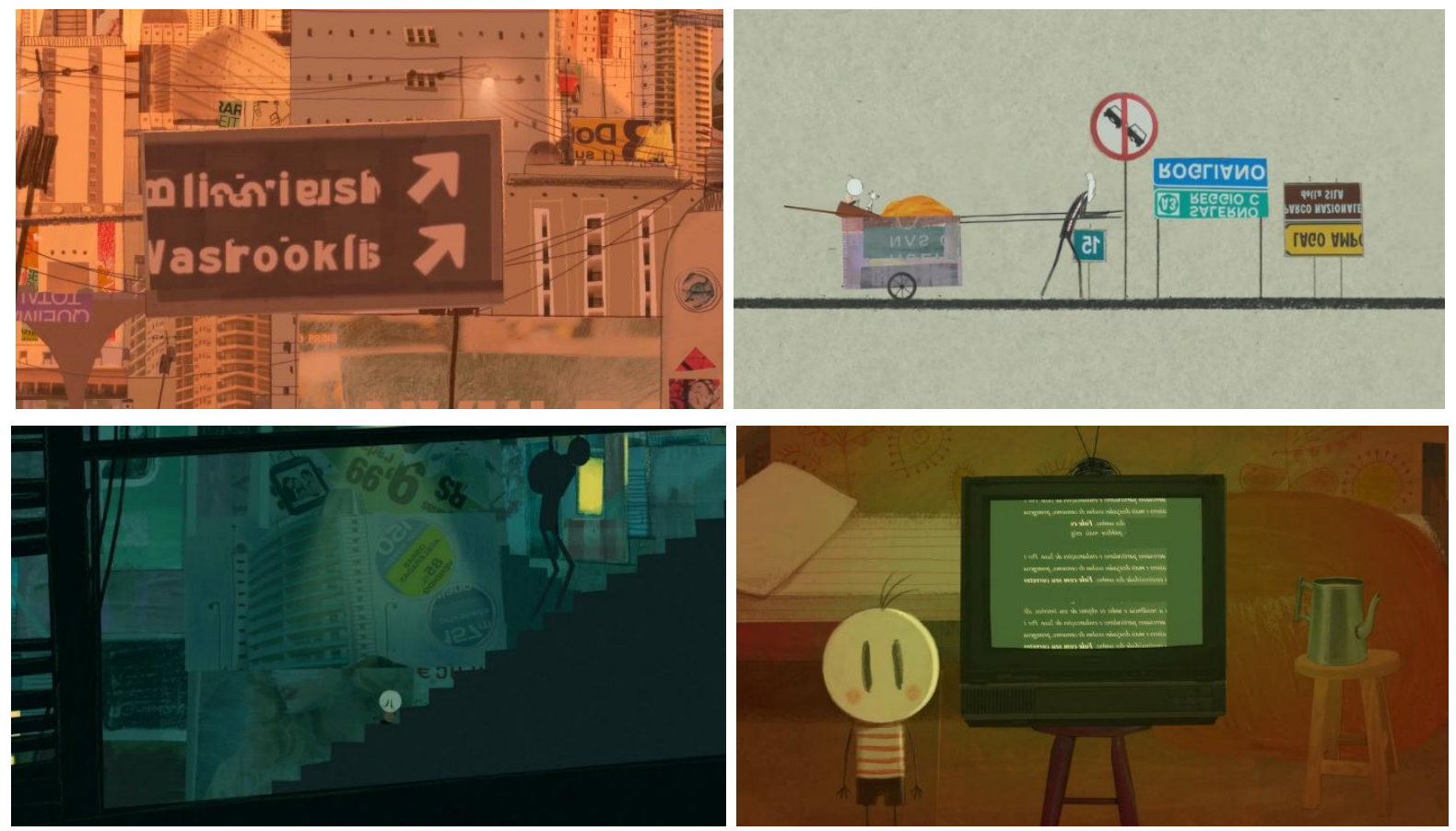

Figura 3: Linguagem verbal no filme

Fonte: Prints Screen capturados em 38'22', 29'38', 40'33" e 43'05", respectivamente, de $O$ Menino e o Mundo (2013).

$\mathrm{Na}$ primeira imagem, por exemplo, as palavras que aparecem na placa de sinalização de trânsito são representadas de forma desfigurada, formando 'letrassímbolos' que não conhecemos. Ao lado, as palavras das placas são dispostas de 'ponta cabeça'. Estratégia semelhante fora aplicada aos números, posicionados de ponta cabeça, como mostra a terceira imagem. E, por fim, na última, identificamos na tela da televisão que os créditos finais também estão invertidos.

A estratégia de inverter a linguagem verbal (falada, cantada e escrita) pode ser lida como uma evidência de que, para Cuca e para outras crianças, são as imagens - e não o verbal - o primeiro e principal artifício narrativo e expressivo. Isso nos remete à defesa de Moreira (2008, p. 20) quando afirma que "a criança desenha para falar e poder registrar sua fala. Para escrever. O desenho é a sua primeira escrita". De acordo com o próprio diretor, Alê Abreu, o filme todo é uma tentativa de apropriação da liberdade que a criança tem ao desenhar, com a potencialidade de inventar qualquer coisa, criando um ambiente quase surrealista ao se deixar levar pela ótica do personagem principal. Assim, Ale Abreu não se limita a desenhos, traços ou cores estereotipadas que muitas vezes 
somos ensinados a reproduzir quando crianças. De maneira lúdica, o filme representa os espaços e as configurações do mundo contemporâneo, com seus problemas e desafios, a partir do olhar de uma criança.

A secundarização da linguagem verbal em relação à visual pode ser identificada quando se recorre à cor enquanto elemento formal das Artes Visuais para representar sons. Em algumas cenas de O menino e o Mundo (2013), os ruídos e vozes são materializados em bolhas coloridas que saem dos instrumentos, rodeando as pessoas enquanto elas cantam. As bolhas indicativas dos sons flutuam pelo ar e simbolizam características sonoras específicas. Supõe-se que seria possível ver o som produzido, e até mesmo 'guardá-los' em um recipiente a partir da captura dessas bolhas - como faz o garoto no início do filme ao ouvir seu pai tocar e, em algumas das cenas, em que ele acaba acessando essa música 'guardada'. Nessas cenas, ele coloca o recipiente em seus ouvidos para lembrar, provavelmente, de seu pai, como destacamos em uma das imagens da Figura 4.

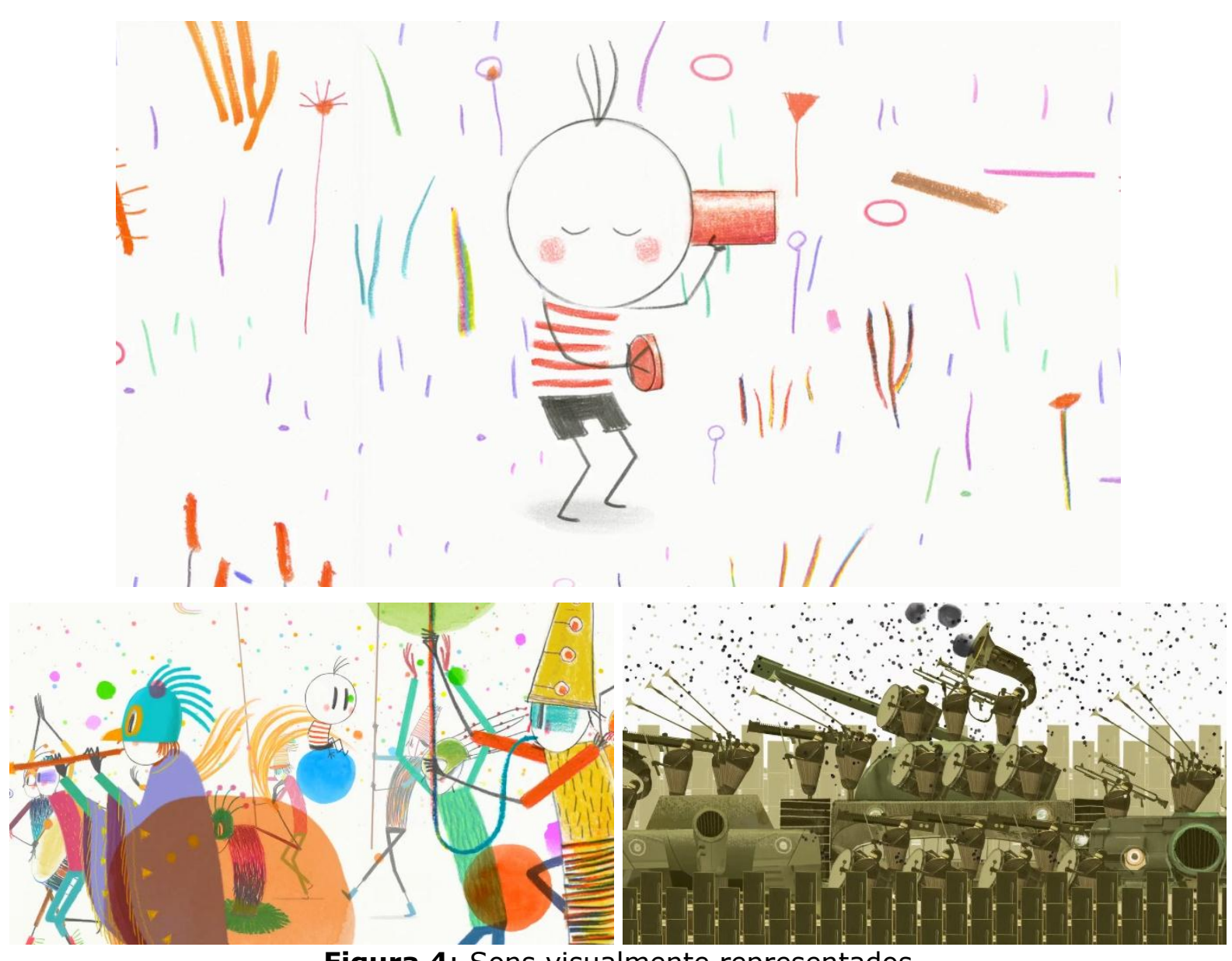

Figura 4: Sons visualmente representados

Fonte: Prints Screen capturados em 25'53", 61' 15' e 12'32', respectivamente. O Menino e o Mundo (2013). 
Há de se destacar uma cena de manifestação popular, mostrada ao som da música Airgela6 - 'alegria' ao contrário. A música é de melodia alegre composta por vozes de pessoas diferentes. Durante essa manifestação popular, a representação visual do som é feita a partir de bolhas coloridas que, por vezes, levam o garoto a flutuar, brincar e dançar por meio delas. Por outro lado, os sons produzidos pelo exército que age para a contenção desta manifestação são visualmente representados por bolhas escuras e mais duras, e sonoramente por vozes mais graves e semelhantes entre si.

Para além da cor, consideramos que O Menino e o Mundo (2013) se utiliza de traços que fazem referência ao imaginário e ao universo das crianças, sugerindo relações com o desenho infantil. O preenchimento cromático dos elementos visualmente representados na animação, tais como plantas, animais e objetos, não respeita exatamente as linhas dos contornos - estética esta que nos remete ao desenho produzido por crianças e reforça a hipótese de que o filme materializa a visão da criança protagonista. Nessa análise, portanto, a animação se propõe a explorar o mundo imagético infantil, relacionando-o com as formas expressivas a partir das quais as crianças experimentam o desenho. Cunha (1999, p. 9) destaca esse mundo de inventividade infantil nas Artes Visuais e especificamente no desenho, ao afirmar que:

As crianças de fato fazem arte ao bagunçarem o mundo imagético das formas convencionais promovendo a desordem lógica no mundo adulto, através dos borrões, fileiras de círculos raiados, manchas, pessoas voando. Nesse espaço lúdico-plástico, gatos e pássaros convivem amigavelmente na mesma superfície, na imaginação e na memória afetiva. Universos convencionais são transformados pela imaginação e inventividade das crianças, criando paradoxos nunca antes vislumbrados pelos adultos.

As ilustrações que compõem as cenas de O Menino e o Mundo (2013) foram produzidas de maneira quase que artesanal, e depois digitalizadas e animadas no computador. O diretor e sua equipe se utilizaram de técnicas e materiais semelhantes àqueles comentados por Cunha (1999) na citação anterior. Desenhos a lápis de cor, giz de cera, giz pastel, canetinhas coloridas e colagens compõem as personagens e os cenários da animação. Recorrem não só à estética e ao pensamento infantil, mas também a técnicas e materiais associados às infâncias. Como podemos observar na Figura 5, na qual a natureza é apresentada pela variedade de animais, árvores, folhas e flores, pouco habituais no mundo real.

\footnotetext{
${ }^{6}$ O clipe e letra da música Airgela, de Ruben Feffer e Gustavo Kurlat com letra de Gustavo Kurlat, podem ser acessados a partir do link: <https://www.youtube.com/watch?v=6twNrIuekGo>. Acesso em: 02 nov. 2019.
} 


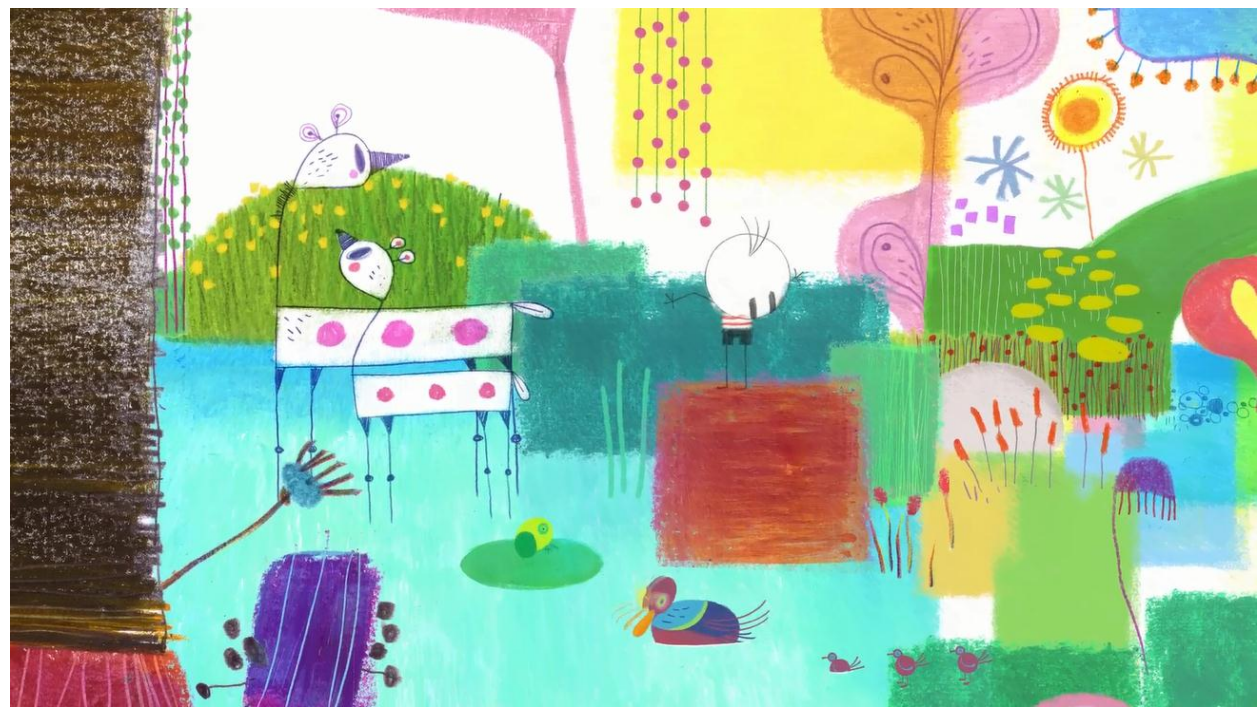

Figura 5: Técnicas artístico-expressivas da animação

Fonte: Print Screen capturado em 4'05", de O Menino e o Mundo (2013)

Os tons mesclados e a heterogeneidade cromática dessas figuras, como aquela marrom sobre a qual Cuca está posicionada, indicam a mistura de cores e o provável contentamento das crianças frente a essa ação.

No que tange às práticas de ensino de Artes Visuais, Sandra Richter (1999, p. 46) observa que "nada [é] mais mágico para a criança do que fabricar, ser um fazedor de cor, para descobrir através da exploração ou perseguir determinado matiz experimentando ludicamente a matéria colorida até alcançar a cor desejada". Para a autora, a criança passa a se interessar pela mistura cromática à medida que surge a curiosidade lúdica ou a intenção/necessidade pela busca de uma cor determinada.

Os animais representados na floresta da Figura 5 também possuem uma estética que foge do realismo e, sobretudo, das imagens estereotipadas que, como observa Maria Letícia Rauen Viana (2010), costumam ser apresentadas e ensinadas às crianças, desde a Educação Infantil. A autora justifica o uso dos estereótipos não só pela falta de conhecimentos e habilidades artísticas das e dos professores e pelo uso de materiais que, tais como o mimeógrafo e a impressora, proporcionam à reprodução de imagens, mas também por uma questão cultural brasileira a partir da qual, no espaço escolar, desenvolveu-se um apreço pela estética da estereotipia. As imagens de animais estereotipados - caracterizados pelos traços econômicos e grossos; pela ausência de texturas e sombreados; pela representação frontal e bidimensional; pelos olhos grandes e pelo acréscimo de laços, aventais, gravatas, cílios e corações como estratégia de marcação de gênero - são frequentemente (re)produzidas pelos/as professores/as que repetem essas esquemas gráficos compulsoriamente. Quando analisa os desenhos de animais produzidos por alunas-já-professoras, a autora percebe que elas não só 
desenham os mesmos animais ${ }^{7}$, como também o fazem de maneiras muito semelhantes. Diante de desenhos de um cachorro e um coelho e de um cachorro e gato, produzido por duas alunas-já-professoras, Vianna (2010, p. 93) avalia que "[...] o que diferencia um animal, desenhado por uma pessoa, de outro, é somente um detalhe, por exemplo, 'as orelhas'".

Diferente disso, os animais representados em O Menino e o Mundo (2013), a exemplo daqueles apresentados na Figura 5, são estruturados de maneiras mais criativas. Aqueles da esquerda apresentam patas e pescoços mais finos que o habitual e manchas coloridas pelo corpo, e o pato por sua vez, é envolvido em uma trama de rabiscos que sugerem movimento - o que nos remete a inventividade do olhar infantil ao explorar e perceber o mundo. Sobre esta ótica do desenho infantil, Cunha (1999, p. 12) destaca que "[...] devemos lembrar que os registros [infantis] resultam de olhares sobre o mundo. Se o olhar é desinteressado e vago, as representações serão opacas e uniformes".

Para além da representação do cenário da animação, os e as personagens também carregam individualidades da estética do desenho infantil. A massa e textura características do uso do lápis - aos quais podemos nos referir como 'rabiscos' ou garatujas - por exemplo, cooperam para a criação de personagens e, às vezes, ultrapassam as linhas dos contornos que, em situações habituais, indicariam o limite da cor. Na estrutura e caracterização do desenho do personagem protagonista, Cuca (Figura 6), podemos observar traços simples, que se afastam de uma representação fidedigna de um menino real. Seus traços são resultantes do uso do lápis de escrever e lápis de cor, conservando as texturas dessas materialidades. A cabeça redonda (com apenas alguns fios de cabelo saltando sobre ela) e os membros representados por esquematizações simples e compostos por longas linhas que parecem ter sido 'rascunhadas' com lápis de escrever são indicativos da maneira de desenhar da criança. Além disso, o corpo de Cuca é definido por linhas vermelhas horizontais em lápis de cor (que dão forma a uma camiseta listada) além de uma bermuda 'rabiscada' com lápis preto. Cuca possui olhos estreitos e bochechas avermelhadas, e não há boca - fator esse que, em nossa análise, reitera que o filme secundariza o aspecto verbal, já que, pelo menos simbolicamente, retira a capacidade de fala dos personagens. Assim, a expressão do garoto é comunicada, sobretudo, por seus olhos e pelos movimentos de seu corpo.

\footnotetext{
${ }^{7}$ A autora constatou que todas as alunas-já-professoras participantes, sem exceção, desenharam um coelho. Gato e cachorro foram o segundo e terceiro animal mais representados. Esquilo, foca, hipopótamo, javali e rato, por sua vez, foram os animais desenhados uma única vez (VIANNA, 2010).
} 

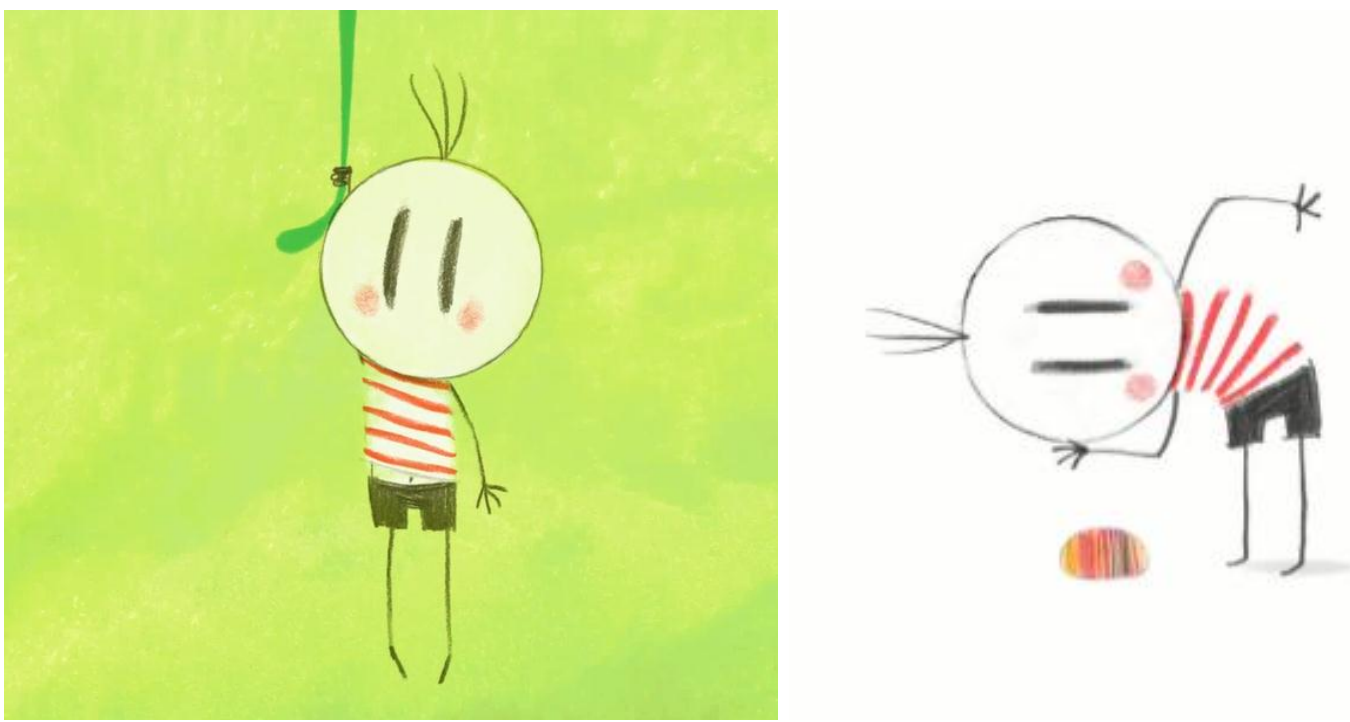

Figura 6: Cuca

Fonte: Prints Screen capturados em 5'58' e 3'26", de O Menino e o Mundo (2013)

As formas simplificadas e, sobretudo, a cabeça arredondada marcam estágios específicos do desenho infantil que inicialmente se manifestam em rabiscos longitudinais, rabiscos circulares e rabiscos nomeados, como assinala Moreira (2008). A autora explica que, em contato com materiais riscantes, os primeiros desenhos das crianças são rabiscos longitudinais - traços de vai e vem que estão mais interessados nos movimentos e com o jogo do que com os registros em si. Tanto que, segundo a autora, a cor, nesse momento, aparece por acaso e não por necessidade da criança. Aos poucos, esses traços se modificam e vão se arredondando, espiralando-se, enovelando-se em emaranhados de linhas, até formarem os primeiros rabiscos circulares, as bolinhas.

Sobre isso, podemos mencionar os estudos de Moreira (2008, p. 31), que explica que a "[...] conquista dos círculos marca uma etapa bastante importante, é o esboço de uma representação. Esboço, porque ainda são acidentais muitas vezes, porém marca geralmente o início de uma necessidade de nomear os desenhos". Essa necessidade indica o início da representação, isto é, o caráter de jogo simbólico a partir do qual a criança conta algo ao desenhar. É importante destacar que, nesse caso, a nomeação nunca é permanente e definitiva, pelo contrário, como evidencia a autora, esses "[...] nomes variam sempre: o que era um elefante, dali a instantes pode ser um carro; contudo está sempre presente a intenção de dizer algo. Agora já podemos considerar o desenho como linguagem" (MOREIRA, 2008, p. 34). Daí por diante, se houver incentivo e condições para que o desenho da criança se desenvolva, vão aparecendo outras figuras fechadas, os primeiros bonecos e formas esquematizadas, e a cor, até então indiferenciada, começa a ser usada de modos estratégicos. E são essas características do 
desenho infantil que identificamos na construção dos e das personagens de $O$ Menino e $O$ Mundo (2013).

Ao comentar as etapas do desenvolvimento do desenho infantil, Betty Edwards (2000, p. 91, grifos nossos) descreve as produções gráficas das crianças e, ao fazê-lo, remete-nos a construção esquemática de Cuca, protagonista de O Menino e o Mundo (2013):

As crianças sentem um intenso prazer em desenhar círculos com olhos, boca e linhas inferiores que representam braços e pernas [...]. Por volta dos três anos e meio, as imagens utilizadas na arte infantil tornam-se mais complexas, refletindo a crescente percepção da criança em relação ao mundo que a cerca. A cabeça passa a ser ligada a um corpo, embora este possa ser menor que a cabeça. É possível que os braços continuem saindo da cabeça, mas geralmente emergem do corpo - às vezes abaixo da cintura. E as pernas são ligadas ao corpo.

Nesse ponto, consideramos ser necessário sublinhar que a aquisição dessas técnicas e o desenvolvimento do desenho infantil não são espontâneos e tampouco concebidos a partir de predisposições inatas, como pressupõem, por exemplo, a justificativa de que algumas pessoas tem o 'dom' para o desenho, outras não. Em outros estudos (BALISCEI, LACERDA, TERUYA, 2018; LACERDA, BALISCEI, TERUYA, 2017) temos defendido que o desenho é uma habilidade aprendida e desenvolvida, conforme a criança é ensinada - e nesse sentido, a atuação de professores e professoras, sobretudo aqueles/as que trabalham com o ensino de Artes Visuais, torna-se fundamental. $O$ pensamento de Rosa Iavelberg (2013, p. 29) contribui para essa argumentação, quando explica que "[...] o desenho infantil autoral não avança apenas porque uma ação da criança leva a outra, e assim sucessivamente, de modo autodidata, espontâneo e natural" e que quem desenha precisa ser desequilibrado/a pela ação educativa intencional.

A partir dessa perspectiva, podemos questionar concepções comumente relacionadas ao ensino de Artes Visuais, tais como a de que professores/as não devem propor modificações e tampouco interferir no desenho da criança; ou ainda, de que não é apropriado que uma criança copie de outra ou que use de referência para produzir seu desenho. A autora destaca que os desequilíbrios proporcionados pelos/as docentes quando propõem que a criança desenhe de maneiras diferentes daquelas com as quais ela já está habituada atuam como desafios a partir dos quais o sujeito infantil tem a oportunidade de aprender. Semelhantemente, Cunha (1999, p. 30) sublinha que a compreensão de que as crianças são fontes inatas e inesgotáveis de criatividade é uma herança da concepção espontaneísta do ensino de Artes Visuais e destaca que: 
Se o educador percebe, por exemplo, que as crianças representam o cabelo sempre do mesmo modo, então é o momento de fazermos uma pesquisa junto com as crianças sobre tipos e cores de cabelos, penteados atuais, de outras épocas históricas e de outros povos, etc., para que elas tenham oportunidade de investigar outras possibilidades de representá-lo.

Contudo, como abordado em outro estudo de Cunha (2017, p. 16), nas escolas contemporâneas, é ainda bastante comum que o potencial criativo das crianças seja tomado como um "[...] inato, e não como um exercício árduo de conhecimento e de elaboração contínua". Dessa forma, a autora compartilha da compreensão de que o imaginário infantil precisa ser ampliado com referências e desafios à medida que os desenhos das crianças passam a reproduzir as mesmas temáticas e estruturas.

Outro aspecto que nos mostra a construção da visualidade de $O$ Menino e o Mundo (2013) a partir do olhar do menino é a forma escolhida para representar as máquinas e os veículos, como podemos observar na Figura 7.
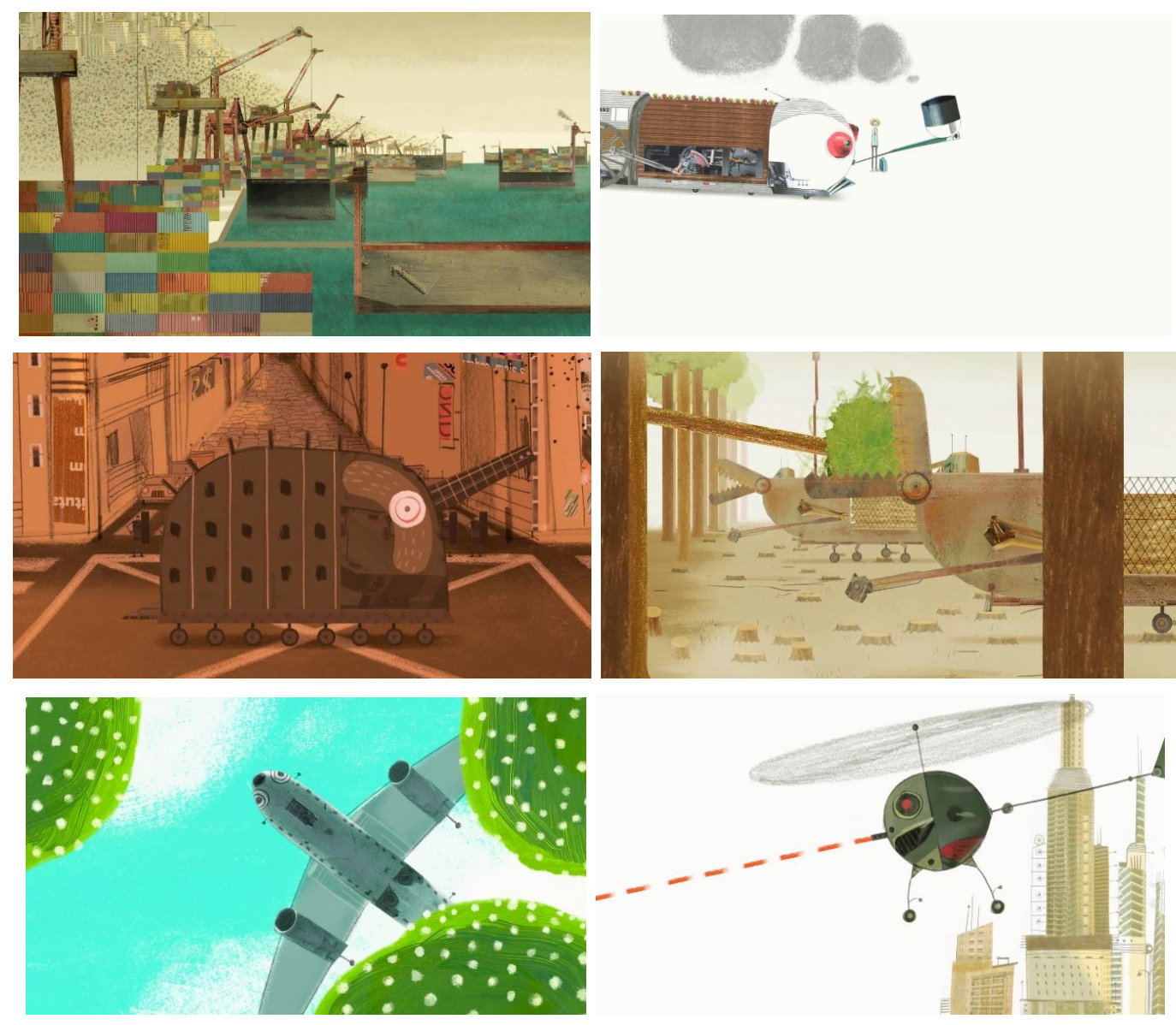

Figura 8: Máquinas-bichos.

Fonte: Prints Screen capturados em 3'83', 27'35', 48'12'", 64'43'", 37'52" e 62'04', respectivamente. O Menino e o Mundo (2013). 
Quando o trem aparece na estação para levar o pai até a cidade, por exemplo, o menino o vê como uma espécie de centopéia com olhos grandes e vermelhos e, nessa lógica imaginativa, a chaminé por onde a locomotiva solta a fumaça é vista como um grande cachimbo. O avião também é representado com olhos, como se fosse um grande pássaro sobrevoando o céu. Os guindastes, por sua estrutura alongada e esguia, são representados semelhante a girafas, cujos pescoços se abaixam e se levantam para transportar as caixas dos navios do porto. Além disso, quando o menino se depara com as máquinas que desmatam a natureza, ele as enxerga como grandes monstros devoradores de árvores. As máquinas utilizadas pelo exército também são apresentadas como animais: o canhão se assemelha a um elefante, e o helicóptero, a um inseto voador.

Iavelberg (2013, p. 47) destaca que no desenho "[...] a criança reflete, intui, age com materiais em suportes e vive uma relação simbólica com o seu trabalho". Dessa maneira, em suas produções os pequenos dialogam, participando de uma espécie de brincadeira de 'faz de conta' que guia as suas ações expressivas, dentre elas, as que envolvem o desenho. Assim, supomos que ao elaborar máquinas e veículos metamorfoseados com características e expressões animais, O Menino e o Mundo (2013) alude ao 'faz de conta' e à ludicidade intrínsecos ao desenho da criança ao mesmo tempo em que denuncia os aspectos animalescos e monstruosos da destruição da natureza.

Na Figura 8, por exemplo, reunimos uma sequência de cenas em que Cuca brinca na natureza. Chega, até mesmo, a 'andar pelas nuvens' e brincar com elas como se fossem algodão. Em seguida, porém, o garoto acaba desestabilizado por uma névoa de cor escura, diferente do cenário colorido e alegre que tinha sido mostrado. Curioso, Cuca passa a se atentar aos sons provocados por uma locomotiva que solta fumaça. Os resquícios da poluição deixados por ela o fazem despencar das nuvens e cair de volta na paisagem natural onde Cuca se encontrava até então.

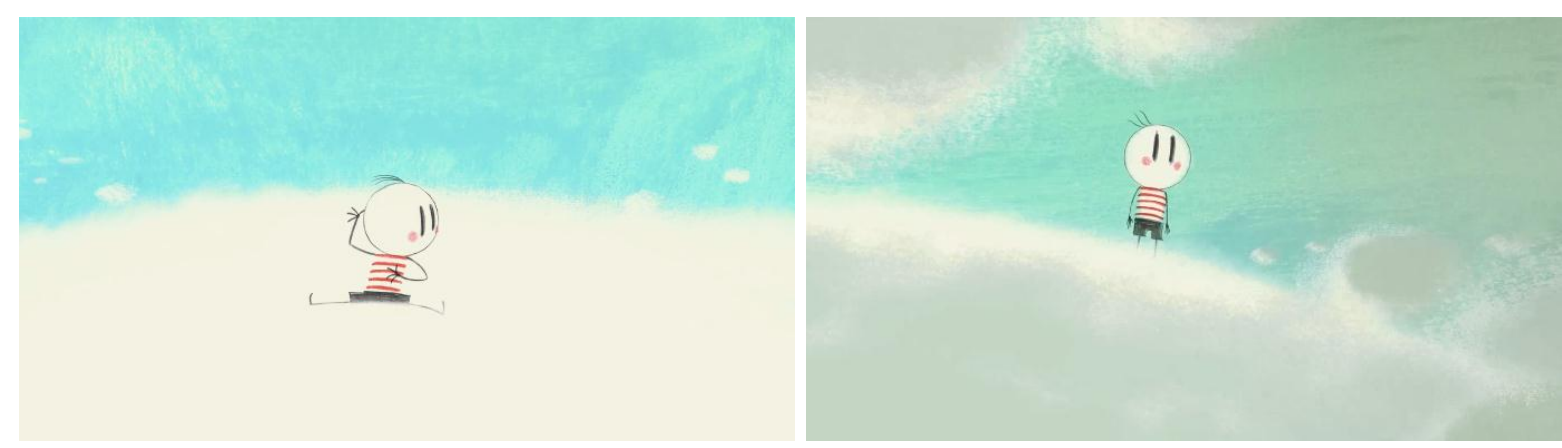




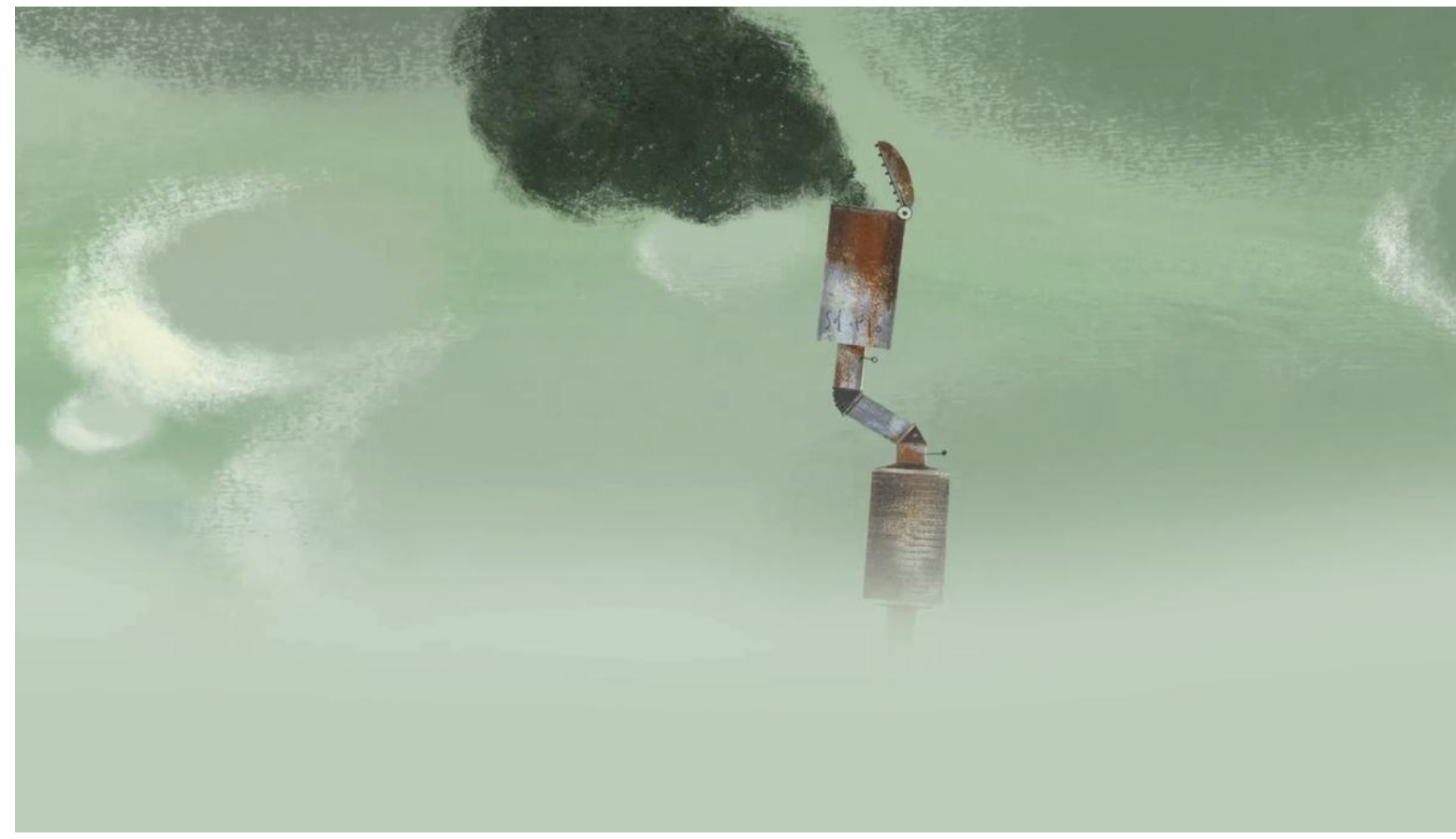

Figura 9: Encontro com a tecnologia

Fonte: Prints Screen capturados em 5'13" e o 5'28', de O Menino e o Mundo (2013)

Podemos relacionar essa cena com o mundo imagético infantil e com os espaços que as sociedades contemporâneas têm destinado às crianças. Sobre isso, Moreira (2008, p. 54) argumenta que "a sociedade industrial, que afasta o homem de suas manifestações expressivas e reserva para a arte um lugar separado do cotidiano, separa também o lugar destinado à infância".

A animação O Menino e o Mundo (2013), então, representa visualmente as implicações que envolvem o ser criança no campo e na cidade. A ideia de progresso tecnológico é abordada não apenas pela locomotiva em si e pelo simbolismo que ela representa enquanto possibilidade de deslocamento geográfico, mas também pelos aspectos gráficos da arte digital e computadorizada empregados na composição desse meio de transporte. Nesse ponto, a locomotiva - e, em seguida, toda a estética da cidade - mostram-se diferentes dos traços orgânicos que caracterizavam a paisagem natural do campo. Além disso, as cores menos saturadas da locomotiva assim como da fumaça emitida por ela sugerem tensão e rompimento com as cenas coloridas que até então eram mostradas. Observamos, ainda sobre essa cena, que os movimentos da máquina também são animados de maneira mecânica e repetitiva, bem diferente da animação fluída e espontânea dos animais e das plantas que ocupavam os cenários anteriores. Por fim, destacamos nossa interpretação quanto ao contraste entre os ambientes rurais e naturais do campo e as paisagens modificadas/industriais da cidade, percebido, por exemplo, na escolha dos materiais artístico-expressivos. Se as primeiras 
cenas se utilizam de materialidades mais artesanais para aludir às características do campo, nas cenas ocorridas na cidade, as técnicas são outras.

Nas cenas que mostram bairros mais pobres e marginalizados das cidades, recorrem-se à colagem e à sobreposição de elementos - o que coopera, de um lado, para caracterizar o ambiente onde as casas são construídas quase umas sobre as outras, e por outro, para causar a sensação de confusão e de acúmulo de pessoas em um lugar só. As diferenças que perpassam as representações do campo e da cidade em $O$ Menino e o Mundo (2013) podem ser observadas na Figura 9.
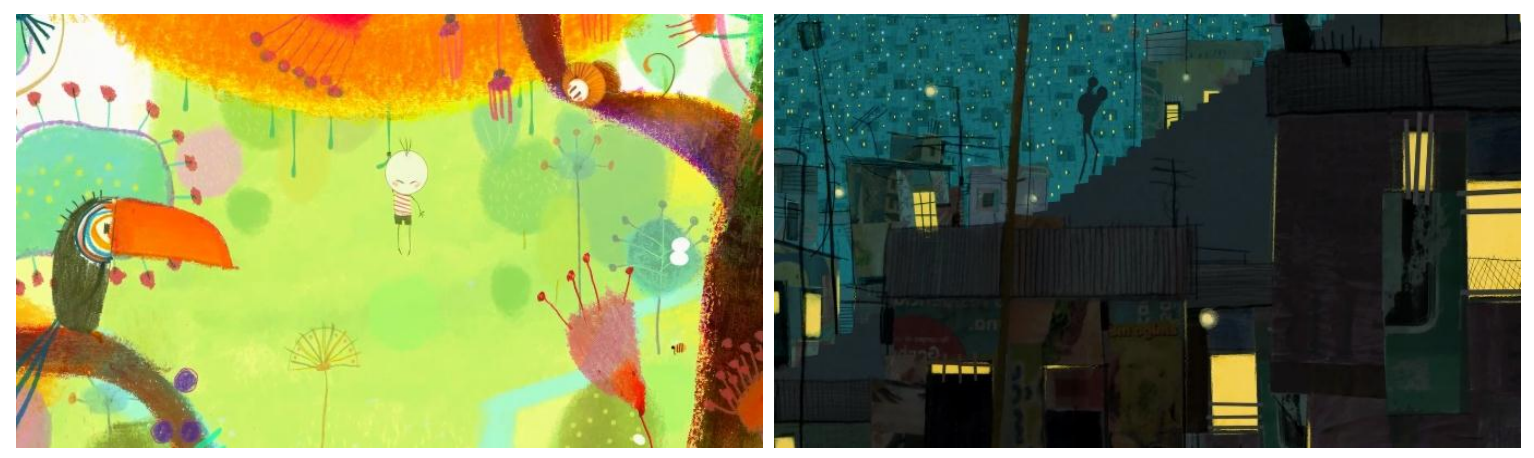

Figura 9: Campo e cidade

Fonte: Prints Screen capturados em 06'05" e 40'49", respectivamente, de O Menino e o Mundo (2013).

As diferenças intrínsecas entre a casa do campo e a casa da cidade onde a família protagonista vive também podem ser pontuadas como elemento visual metafórico dos significados que permeiam a vida nesses dois contextos. Como destacamos na Figura 10, as cores e texturas aplicadas à visualidade da casa do campo denotam elementos naturais, como a madeira e o barro, ao passo que, para a caracterização da casa da cidade, recorreram-se à sobreposição de papéis nas superfícies das paredes, à colagem de móveis extraídos e à representação em três dimensões - o que pode ser aproximado dos estudos de design de interiores e de móveis planejados.
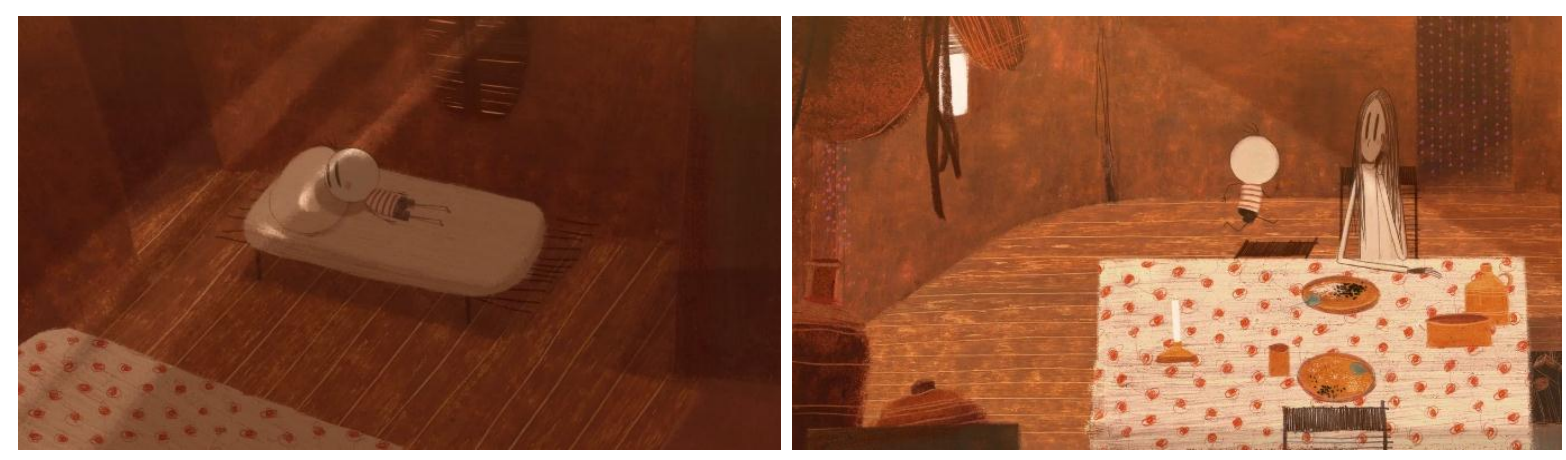

Revista Digital do LAV - Santa Maria - vol. 13, n. 3, p. 05 - 30 - set./dez. 2020 ISSN 1983 - 7348 http://dx.doi.org/10.5902/1983734841970 


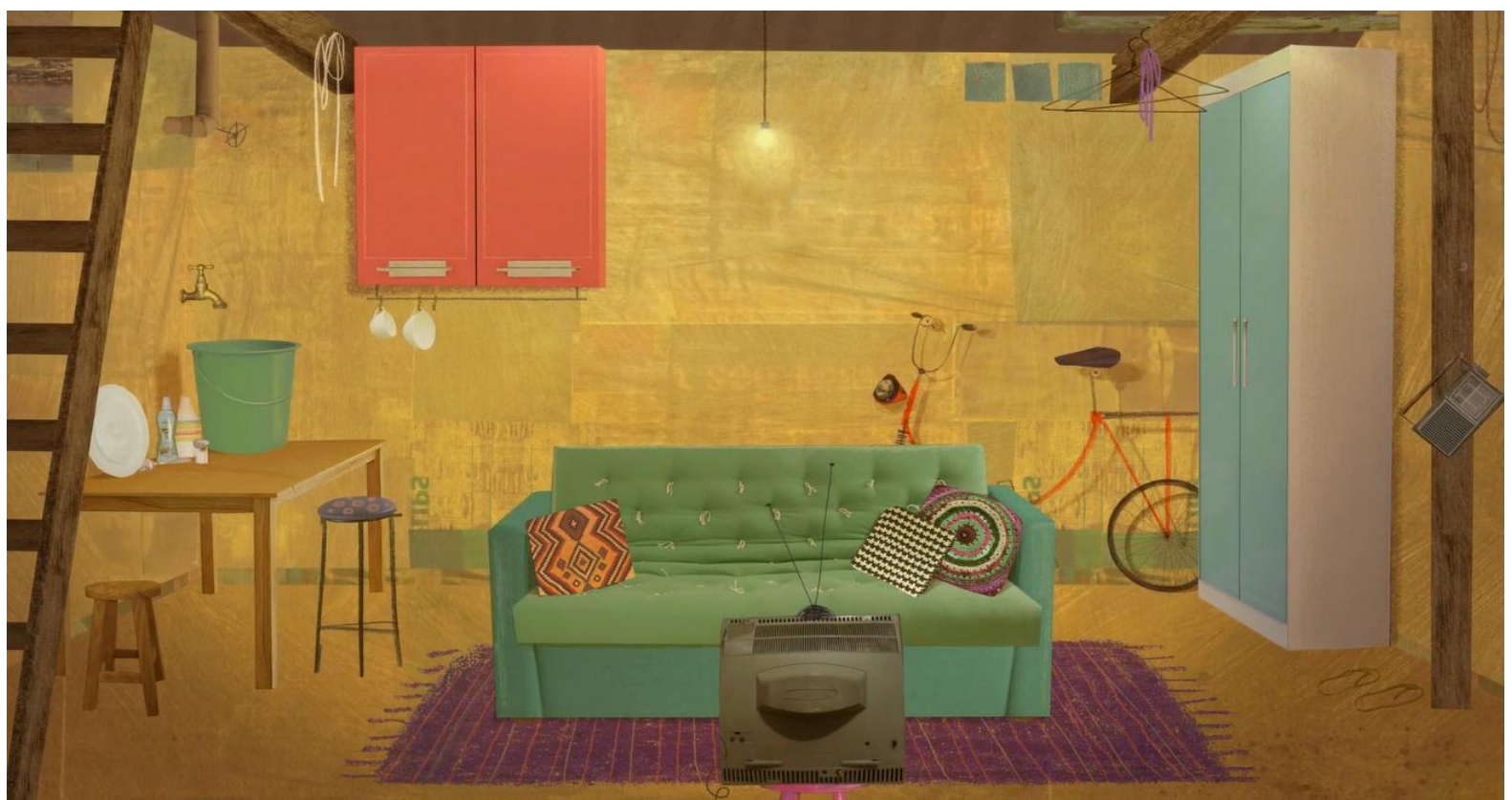

Figura 10: Casa do campo e casa da cidade

Fonte: Prints Screen capturados em 41'21'", 4'03", e 15'32", respectivamente, de O Menino e o Mundo (2013)

É importante destacar que esse conjunto de cenas selecionadas não esgota as possíveis análises da animação, tampouco os temas e pensamentos que podem se desdobrar dela. Para além de questões que perpassam o desenho infantil e a própria concepção de infância, O Menino e o Mundo (2013) oferece significados visuais acerca das questões de classes (conflitos entre trabalhadores/as rurais, trabalhadores/as da fábrica e o dono da fábrica), ambientais (desmatamento e destruição da natureza), políticas (embates entre manifestantes e exército) e midiáticas (interação com a televisão, a publicidade, a moda e o consumo).

\section{Considerações Finais}

Nessa reflexão, verificamos que, mesmo com toda tecnologia que atualmente nos é disponível, em O Menino e o Mundo (2013) houve a escolha/intenção por parte do diretor sobre produzir um filme quase que manualmente. Tal escolha foi interpretada por nós como um reforço da criação de uma narrativa advinda de uma perspectiva infantil. Quais significados acerca da infância podem ser produzidos a partir das visualidades fílmicas de O Menino e o Mundo (2013)? Para responder esse problema de pesquisa lançado na introdução, tivemos o objetivo de investigar as características estéticas da animação em questão, relacionando-as com o desenho infantil e com significações sobre a infância. 
A partir da escolha de um conjunto de cenas da animação, estabelecemos relações entre os elementos estéticos e narrativos e as peculiaridades do desenho infantil e da própria concepção de infância. Nesse ponto, os pressupostos teórico-metodológicos dos Estudos da Cultura Visual contribuíram para os exercícios de análise de imagem que propusemos, pois nos incentivaram não só a explorar as diversas camadas interpretativas que um mesmo artefato cultural oportuniza, como também a refletir sobre os aspectos identitários que tal artefato tematiza. Permitiram-nos, também, discutir sobre a construção do visual na Arte, nas mídias e na vida cotidiana, relacionando-a com contextos sociais, culturais, políticos e econômicos, e levar em conta, ainda, a visão de mundo da personagem como parte fundamental na construção da narrativa.

As cenas de O Menino e o Mundo (2013) denotam uma secundarização da linguagem verbal em relação aos aspectos gráficos e artísticos a partir dos quais a criança percebe e se expressa no mundo. Os materiais utilizados se assemelham àqueles associados às infâncias e os modos de utilizá-los, por sua vez, aproximam-se das maneiras particulares como as crianças desenham. Nesse sentido, em nossa análise, estabelecemos relações de analogia entre os aspectos estéticos da animação e características específicas dos desenhos infantis, tais como os rabiscos longitudinais, os rabiscos circulares, as garatujas e os desenhos de representação.

Ressaltamos, por fim, que essas interpretações foram possíveis de serem formuladas ainda que o filme em questão não recorra à linguagem verbal, ou pelo menos, não atribua a ela o protagonismo narrativo da história. Enquanto assistíamos e analisávamos O Menino e o Mundo (2013), percebemos que não fora escrita ou dita qualquer palavra completamente decodificável. Demonstramos, a partir dessa reflexão e recorrendo a essa animação como exemplo, a potencialidade dos recursos visuais para produção de mensagens, significados e conhecimentos que - diferente das letras e palavras - podem ser lidos de maneiras variadas.

\section{Referências}

BALISCEI, J. P. Provoque: Cultura Visual, Masculinidades e ensino de Artes Visuais. Rio de Janeiro: Metanoia, 2020.

BALISCEI, J. P.; LACERDA, E.; TERUYA, T. K. "Eu não sei desenhar": Questionando dons e outras habilidades supostamente excepcionais presentes no Ensino de Arte. Revista Imagens da Educação, Maringá, v. 8, n. 1, p. 1-13, 2018. Disponível em: <http://periodicos.uem.br/ojs/index.php/ImagensEduc/article/view/32375/pdf>. Acesso em: 6 abr. 2018. 
HOLZER, J. BLUE Purple Tilt. Nova York, 2007. Disponível em: <https://www.itsnicethat.com/news/jenny-holzer-artist-rooms-tate-modern-exhibition240718>. Acesso em: 20 jun. 2019.

BRASIL. Base Nacional Comum Curricular. Ministério da Educação. Secretaria de Educação Básica: Brasília, 2018.2 Disponível em: <http://basenacionalcomum.mec.gov.br/a-base>. Acesso em: 6 abr. 2018.

CUNHA, S. R. V. da. Pintando, bordando, rasgando, desenhando e melecando na educação infantil. In: CUNHA, S. R. V. da. (org.) Cor, som e movimento: a expressão plástica, musical e dramática do cotidiano. Porto Alegre: Editora Mediação, 1999, p. 717.

CUNHA, S. R. V. da. Uma Arte do nosso tempo para as crianças de hoje. In: CUNHA, S. R. V. da; CARVALHO, R. S. de. Arte Contemporânea e educação Infantil: Crianças observando, descobrindo e criando. Porto Alegre: Mediação, 2017, p. 9-25.

DONDIS, D. A. A sintaxe da linguagem visual. São Paulo: Martins Fontes, 2014.

EDWARDS, B. Desenhando com o lado direito do cérebro. Rio de Janeiro: Ediouro, 2000.

HERNÁNDEZ, F. Catadores da Cultura Visual. Porto Alegre: Editora Mediação, 2007.

IAVELBERG, R. Desenho na educação infantil. Coleção Como eu ensino. São Paulo: Editora Melhoramentos, 2013.

LACERDA, E. A.; BALISCEI, J. P.; TERUYA, T. K. Riscos, rabiscos e rascunhos: Analisando desenhos de crianças e idosas. Revista Eletrônica Pesquiseduca, Santos, v. 9, n. 17, p. 289-249, 2017. Disponível em: <http://periodicos.unisantos.br/index.php/pesquiseduca/article/view/593>. Acesso em: 22 nov. 2017.

MOREIRA, A. A. O Espaço do Desenho: A educação do Educador. São Paulo: Edições Loyola, 2008.

O MENINO e o mundo. Direção: Alê Abreu. Produtora: Filme de Papel. São Paulo, 2013. 85 min. Bobina Cinematográfica.

BANKSY. O filho de um imigrante da Síria. França, 2015. Disponível em: <https://observador.pt/2015/12/12/steve-jobs-era-filho-um-imigrante-sirio-lembrabanksy>. Acesso em: 20 jun. 2019.

FONZÁLEZ-TORRES, F. Perfect Lovers. Nova York, 1991. Disponível em: <https://www.moma.org/collection/works/81074>. Acesso em: 20 jun. 2019.

RICHTER, S. Manchando e Narrando: o prazer visual de jogar com cores. In: CUNHA, S. R. V. da. (org.) Cor, som e movimento: a expressão plástica, musical e dramática do cotidiano. Porto Alegre: Editora Mediação, 1999, p. 37-55.

SANTAELLA, L. Leitura de imagens. Coleção Como eu ensino. São Paulo: Melhoramentos, 2012.

SARDELICH, M. E. Leitura de imagens, Cultura Visual e prática educativa. Cadernos de Pesquisa, São Luís, v. 36, n. 128, p. 451-472, maio/ago., 2006. Disponível em: <http://www.scielo.br/pdf/cp/v36n128/v36n128a09.pdf>. Acesso em: 20 jan. 2020. 
KRUEGER, B. UNTITLED (Your Body Is a Battleground). 1989. Disponível em: <https://www.wikiart.org/en/barbara-kruger/untitled-your-body-is-a-battleground1989>. Acesso em: 20 jun. 2019.

VIANNA, M. L. R. Desenhando com todos os lados do cérebro: possibilidades para transformação das imagens escolares. Curitiba: Ibpex, 2010.

' Doutor em Educação (2018) pelo Programa de Pós-Graduação da Universidade Estadual de Maringá com estudos na Facultad de Bellas Artes/ Universitat de Barcelona, Espanha. É professor no curso de Artes Visuais na Universidade Estadual de Maringá e coordenador do Grupo de Pesquisa em Arte, Educação e Imagens - ARTEI. Desenvolve pesquisas sobre Educação, Arte/ Ensino de Arte; Estudos Culturais; Estudos da Cultura Visual; Visualidades; Gênero e Masculinidades.

ii Graduada em Artes Visuais pela Universidade Estadual de Maringá - UEM (2020). Participa do Grupo de Pesquisa em Arte, Educação e Imagens - o ARTEI.

Como citar esse artigo:

BALISCEI, João Paulo; PEREIRA, Emilly Anselmo. Análise da animação o menino e o mundo (2013): significados visuais acerca do desenho infantil e das infâncias. Revista Digital do LAV, Santa Maria: UFSM, v. 13, n. 3, p. 05-30, set./dez. 2020. 